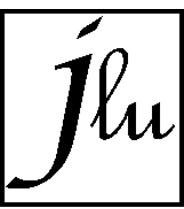

Jurnal Luminous:

Riset IImiah Pendidikan Fisika

Vol. 1 No. 2 (2020) hal 1-10
E-ISSN 2715-6990

P-ISSN 2715-9582

Juli 2020

https://jurnal.univpgri-

palembang.ac.id/index.php/luminous

\title{
FIVE LEVELS CONCEPTUAL CHANGE: PERUBAHAN KONSEPTUAL SISWA MELALUI MODEL LEARNING CYCLE 6E PADA KONSEP DINAMIKA ROTASI
}

\author{
Anifatul Mardiyah ${ }^{1}$, Tantri Mayasari ${ }^{2}$, Farida Huriawati ${ }^{3}$ \\ 1,2,3 Pendidikan Fisika, Universitas PGRI Madiun, JI Setia Budi 85 Kota Madiun \\ E-mail: anifatulmardiyah@gmail.com
}

Received: 28 April 2020. Accepted: 25 Juni 2020. Published: Juli 2020

\begin{abstract}
The learning process can be achieved when there is a change in students' understanding of concepts towards a better direction. These changes can be realized by the existence of an alternative learning model. The purpose of this study was to analyze the conceptual changes experienced by students on the material of rotational dynamics through the learning cycle $6 \mathrm{E}$ learning model. This research is a type of qualitative research with a descriptive approach. The research results obtained are an increase in understanding of student concepts based on the results of the analysis of the pre-test post-test answers and student observation in carrying out learning. The tendency of students shows students A and B in the level of change is in complementation, students $C$ and $D$ are in construction, students $E$ and $F$ are in revision, and students $G$ and $H$ do not experience conceptual change or no conceptual change.
\end{abstract}

Keywords: conceptual change, learning cycle, assessment.

\section{Abstrak}

Proses pembelajaran dapat tercapai ketika terjadi suatu perubahan pemahaman konsep siswa ke arah yang lebih baik. Perubahan tersebut dapat terlaksana dengan adanya suatu alternatif model pembelajaran. Tujuan penelitian ini untuk menganalisis perubahan konseptual yang dialami oleh siswa pada materi dinamika rotasi melalui model pembelajaran learning cycle 6E. Penelitian ini merupakan jenis penelitian kualitatif dengan pendekatan deskriptif. Hasil penelitian yang diperoleh yaitu adanya peningkatan pemahaman konsep siswa berdasarkan hasil analisis jawaban pre-test post-test dan observasi siswa dalam melaksanakan pembelajaran. Kecenderungan level perubahan siswa menunjukkan bahwa siswa A dan B dalam berada pada complementation, siswa $\mathrm{C}$ dan $\mathrm{D}$ berada pada construction, siswa $\mathrm{E}$ dan $\mathrm{F}$ berada pada revision, serta siswa $\mathrm{G}$ dan $\mathrm{H}$ tidak mengalami perubahan konseptual atau no conceptual change.

Kata Kunci: perubahan konseptual, learning cycle, penilaian.

\section{PENDAHULUAN}

Proses belajar pada dasarnya merupakan pembicaraan yang berkaitan dengan perubahan tingkah laku seseorang sebagai akibat dari pengalaman yang diperoleh dari lingkungan
(Hardini \& Puspitasari, 2015). Dalam pelaksanaan pembelajaran di kelas, guru menemukan berbagai permasalahan yang berdampak secara langsung maupun tidak langsung terhadap hasil belajar siswa. Kategori hasil belajar siswa terdiri dari tiga 
indikator yaitu: 1) efektivitas pembelajaran yang dapat diukur dari tingkat keberhasilan dari berbagai sudut, 2) efisiensi pembelajaran yang dukur dari waktu belajar, dan 3) daya tarik pembelajaran terhadap minat belajar siswa (Arsa, 2015). Salah satu permasalahan yang dihadapi adalah konsepsi yang dimiliki siswa sebelum pembelajaran dilaksanakan. Sehingga guru ditutut dapat menyelesaikan permasalahan tersebut dengan menggunakan model pembelajaran yang tepat.

Model pembelajaran siklus belajar atau learning cycle merupakan model pembelajaran sains yang memberikan ruang bagi siswa untuk mengembangkan kemampuan berpikir siswa (Sadia, 2014). Learning cycle dikategorikan sebagai strategi pembelajaran konstruktivisme dengan asumsi jika "pengetahuan dikonstruksi dalam pikiran pebelajar". Aktivitas belajar pada model pembelajaran ini terdiri dari beberapa tahap yaitu fase eksplorasi, fase pengenalan konsep dan fase aplikasi konsep. Ketiga fase ini kemudian lebih dikenal sebagai learning cycle 3E. Kegiatan utama pada pembelajaran ini adalah eksperimen yang dilakukan oleh siswa dengan bimbingan guru seminimal mungkin. Seiring waktu, learning cycle mengalami perkembangan oleh Robert Bybee pada tahun 1997, menurutnya tahapan learning cycle akan lebih baik apabila tahapan yang digunakan lebih terperinci sehingga la mengembangkan tahapan tersebut menjadi engagegement (mengaitkan), explore (eksplorasi), explaination (menjelaskan), elaboration (elaborasi) dan evaluate (evaluasi) sehingga dikenal sebagai learning cycle $5 \mathrm{E}$. Perkembangan learning cycle kini telah mencapai tahap 7E (Eisenkraft, 2003). Perubahan tersebut yaitu tahap elicit dan extend. Model ini mengembangkan engagement menjadi eliciting dan engaging serta tahap elaboration dan evaluation menjadi elaborating, evaluating, dan extending.

Dasar pelaksanaan suatu model pembelajaran adalah bentuk pembelajaran dari pendahuluan hingga penutup yang dapat dimodifikasi oleh guru (Sutirman, 2013). Berdasarkan perkembangan fase aktivitas dalam learning cycle, penelitian ini mengembangkan model learning cycle dengan enam tahapan atau 6E. Pengembangan tersebut dimulai dengan kajian literatur terhadap variasi model pembelajaran untuk meningkatkan kemampuan siswa dalam memahami suatu konsep materi pembelajaran, kemudian peneliti melaksanakan observasi kesulitan-kesulitan yang dialami siswa dalam pemahaman konsep, hingga menentukan model pembelajaran yang efektif untuk memfasilitasi perubahan pemahaman konseptual siswa. Alasan pengembangan model learning cycle 6E yaitu penyesuaian terhadap waktu pembelajaran siswa di Indonesia serta berkaitan dengan penguasaan konsep yang berorientasi pada keaktifan siswa dalam mengeksplorasi pengetahuan dan menerapkan konsep pada kondisi tertentu berdasarkan permasalahan yang dihadapi.

Model learning cycle 6E ini merupakan pemilihan tahapan dari perkembangan learning cycle dari 5E hingga 7E dimana dalam penerapan proses pembelajaran tidak melalui tahap elicit. Tahap elicit merupakan tahap awal pembelajaran untuk mengungkap pengetahuan siswa. Dalam penerapannya tahap ini dilaksanakan untuk memunculkan pertanyaan-pertanyaan untuk mengungkap konsepsi siswa. Kegiatan pada tahap elicit ini, dapat digabungkan dalam tahap engagement dimana guru memberikan suatu kegiatan untuk memusatkan perhatian siswa, merangsang kemampuan berpikir, dan memotivasi siswa untuk tertarik pada materi yang dibahas. Kegiatan tersebut dapat dilaksanakan dengan demonstrasi, diskusi, membaca atau aktivitas lain yang dapat memunculkan pertanyaan serta mengembangkan rasa keingintahuan siswa.

Perubahan konseptual dapat diketahui sebagai suatu bentuk transformasi dari kerangka berpikir awal menuju kerangka berpikir konseptual akhir (Lappi, 2013). Perubahan konseptual disebut sebagai proses mengubah konsepsi sebelumnya dari yang belum tepat menjadi konsepsi ilmiah (Kristianti et al., 2019). Perubahan konseptual juga dapat dimaknai siswa memperluas konsep ataupun merubah konsep yang salah menjadi 
benar (Hudha et al., 2016). Karakteristik perubahan konseptual membutuhkan beberapa indikator, diantaranya yaitu: 1) representasi konseptual awal, 2) representasi untuk hasil, dan 3) spesifikasi model pembelajaran yang telah dimodifikasi dari awal menjadi akhir. Makna pembelajaran dalam prespektif konstruktivis adalah melibatkan perubahan konseptual, utamanya ketika seorang siswa mengalami alternative acception atau lebih dikenal sebagai miskonsepsi (Suratno, 2008). Lebih lanjut, Arends dalam (Hudha et al., 2016) mengungkapkan bahwa suatu perubahan tentu memerlukan suatu proses pembelajaran yang memberikan ruang bagi siswa untuk mengembangkan konsep-konsep yang sudah ada dan mengkonstruksi kerangka berpikir.

Penelitian terdahulu telah membuktikan bahwasanya model pembelajaran learning cycle $6 \mathrm{E}$ dapat meningkatkan pemahaman konsep fisika (Lisma et al., 2017; Veronika, 2017; Zubaidah \& Lestari, 2016). Selain peningkatan pemahaman konsep, learning cycle juga dapat meningkatkan kemampuan berpikir kritis siswa (Partini et al., 2017). Pembelajaran dalam learning cycle membantu siswa untuk berperan aktif dalam mengeksplorasi pengetahuan mereka sehingga motivasi belajar siswa dapat meningkat dan berdampak hasil belajar yang lebih baik (Sari \& Rahmatan, 2017). Penyampaian materi dalam pembelajaran ini dengan mengaitkan hubungan konsep yang sedang dipelajari dengan aktivitas dalam lingkungan sosial yang sering dijumpai siswa, dengan cara tersebut siswa mudah menguasai konsep dan hasil belajar mereka akan meningkat (Imaniyah \& Bakri, 2015; Ozge, 2014; Sulastri \& Hikmawati, 2018; Zuhra et al., 2017).

Pada penelitian ini, penerapan sebuah model pembelajaran yang telah dimodifikasi yakni learning cycle $6 \mathrm{E}$ digunakan sebagai suatu treatment untuk membantu siswa mengalami perubahan konseptual. Tujuan penelitian ini adalah menganalisis perubahan konseptual siswa dengan level perubahan konsepsi terdiri dari 1) construction, 2) complementation, 3) revision, 4) static, dan 5) disorientation. Perubahan tersebut diketahui berdasarkan hasil pre-test dan post-test serta observasi keterlaksanaan model pembelajaran learning cycle $6 \mathrm{E}$.

\section{METODE}

Penelitian ini termasuk dalam penelitian desain kualitatif dengan melibatkan siswa kelas $X$ jurusan Teknik Kendaran Ringan Otomotif Sekolah Menengah Kejuruan disalah satu sekolah yaysan swasta di Kota Madiun. Pelaksanakan penelitian ini selama kurang lebih 3 bulan dari bulan September hingga Desember 2019 secara bertahap. Penelitian ini berbeda dari penelitian yang dilakukan oleh Syahrul \& Setyarsih (2015). Hasil penelitian ini dapat mengidentifikasi perubahan konseptual siswa berdasarkan level kategori konsepsi siswa. Identifikasi kategori konsepsi siswa menggunakan sebuah instrumen tes diagnostik yang telah dikembangkan oleh peneliti yaitu Rotational Dynamics Conceptual Survey (RDCS). Pengembangan instrumen tes ini berdasarkan pada bentuk multiple tier choice test dengan format four-tier. Jumlah soal pada instrumen RDCS sebanyak 18 soal yang dibagi menjadi dua bagian yang diberikan pada pre-test dan post-test dengan indikator soal yang sama.

Tipe pertanyaan yang digunakan dalam instrumen Rotational Dynamics Conceptual Survey pada pre-test dan post-test adalah tes pilihan ganda bertingkat dengan empat tingkatan. Bentuk pertanyaan seperti ini dapat mengidentifikasi empat kategori konsepsi siswa berdasarkan kombinasi jawaban pada tier-1, confidence rating pada tier-2, alasan memilih jawaban pada tier-3, dan confidence rating pada tier-4. Kategori konsepsi siswa bertujuan untuk merangkum kombinasi jawaban siswa pada pre-test dan posttest, selanjutnya dikelompokkan berdasarkan tingkat jawaban. Deskripsi kategori konsepsi siswa yang digunakan dalam penelitian ini seperti pada Tabel 1.

Tabel 1. Analisis Deskripsi Kategori Konsepsi

Siswa

Kategori $\quad$ Analisis Deskripsi
Konsepsi




\begin{tabular}{ll}
\hline $\begin{array}{l}\text { Kategori } \\
\text { Konsepsi }\end{array}$ & Analisis Deskripsi \\
\hline $\begin{array}{l}\text { Paham } \\
\text { Konsep (PK) }\end{array}$ & $\begin{array}{l}\text { Kesesuaian konsepsi } \\
\text { siswa dengan konsep } \\
\text { ilmiah }\end{array}$ \\
\hline Tidak Paham & $\begin{array}{l}\text { Konsepsi siswa belum } \\
\text { Konsep (TPK) }\end{array}$ \\
\hline tepat \\
\hline Miskonsepsi & $\begin{array}{l}\text { Ketidaksesuaian konsepsi } \\
\text { siswa dengan konsep } \\
\text { imiah }\end{array}$ \\
\hline Error (E) & Konsepsi siswa menebak \\
\hline
\end{tabular}

Perubahan konseptual dapat terjadi ketika proses pembelajaran berlangsung secara efektif. Proses pembelajaran ini mengakibatkan konsep yang dimiliki siswa sebelumnya dapat berkembang atau berubah menjadi benar. Oleh sebab itu, dalam penelitian ini perubahan kategori konsepsi dari kombinasi jawaban siswa pada pre-test dan post-test sebagai perbandingan hasil proses pembelajaran. Setiap siswa memili perubahan pemahaman konsep yang berbeda. Perubahan tersebut dapat menghasilkan pemahaman yang lebih baik atau justru kearah yang lebih buruk apabila dibandingkan dengan pemahaman awal. Variasi kategori konsepsi siswa pada pre-test dan post-test menghasilkan level perubahan konseptual yang dialami siswa seperti pada Tabel 2.

Tabel 2. Analisis Level Perubahan Konseptual

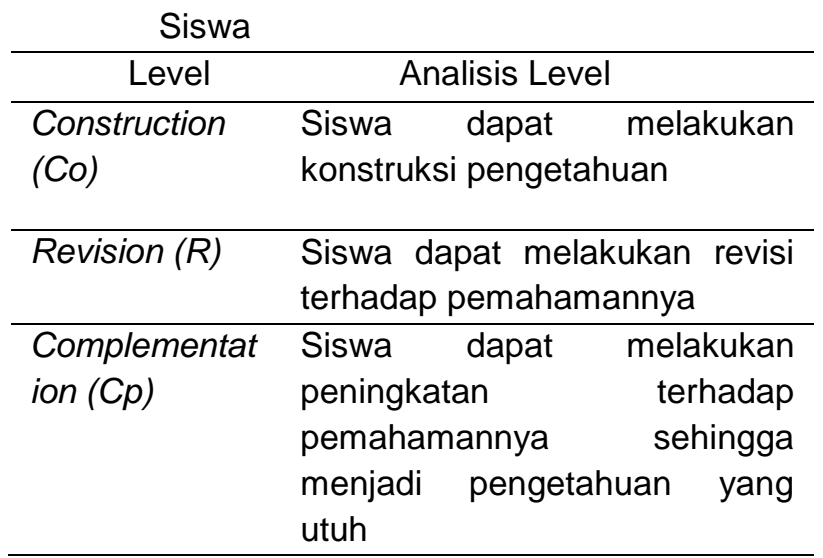

\begin{tabular}{ll}
\hline \multicolumn{1}{c}{ Level } & \multicolumn{1}{c}{ Analisis Level } \\
\hline Static (S) & $\begin{array}{l}\text { Siswa tidak mampu melakukan } \\
\text { perubahan pemahaman } \\
\text { menjadi pemahaman yang lebih } \\
\text { baik }\end{array}$ \\
\hline $\begin{array}{l}\text { Disorientation } \\
\text { (D) }\end{array}$ & $\begin{array}{l}\text { Siswa mengalami perubahan } \\
\text { pemahaman ke kategori yang } \\
\text { lebih buruk }\end{array}$ \\
\hline \multicolumn{2}{c}{ Pada tahap awal, siswa diberikan pre-test }
\end{tabular}
untuk mengetahui level kategori konsepsi siswa. Pre-test ini diberikan kepada siswa kelas $X$ yang telah memperoleh materi dinamika rotasi sebanyak 28 siswa. Dari hasil pre-test tersebut diambil fokus penelitian yakni 8 siswa sebagai subjek penelitian untuk diamati aktivitas mereka dalam mengikuti pembelajaran. Kedelapan siswa yaitu siswa A dan B dikategorikan dalam miskonsepsi, siswa $C$ dan $D$ tidak paham konsep, siswa $E$ dan $F$ error serta siswa $G$ dan $H$ paham konsep. Selanjutnya tahap pelaksanaan model pembelajaran learning cycle $6 \mathrm{E}$, peneliti dibantu observer untuk menilai keterlaksanaan tahap kegiatan belajar learning cycle $6 \mathrm{E}$ dan mengamati aktivitas siswa dalam mengikuti treatment yang dilaksanakan.

\section{HASIL DAN PEMBAHASAN}

Perubahan konseptual yang dialami siswa diperoleh berdasarkan pengalaman dapat diamati selama proses pembelajaran learning cycle 6E dan hasil respon jawaban siswa pada pre-test dan post-test. Level perubahan konseptual siswa indikator definisi momen gaya atau torsi seperti pada Gambar 1.

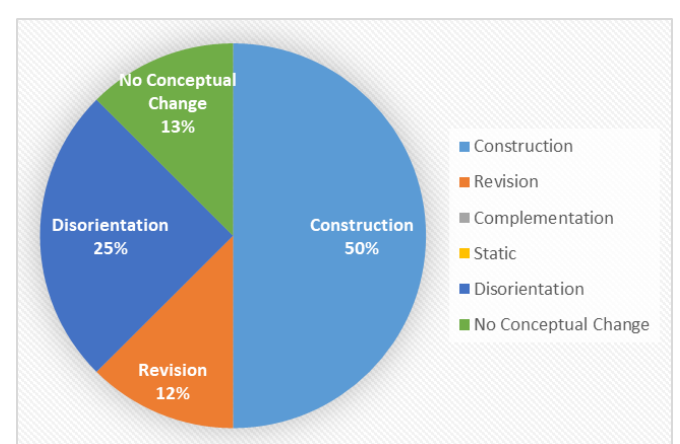

Gambar 1 Level Perubahan Konseptual Pada Topik Definisi Momen Gaya 
Hasil respon siswa pada indikator soal nomor 1 menunjukkan level perubahan konseptual seperti pada Gambar 2.

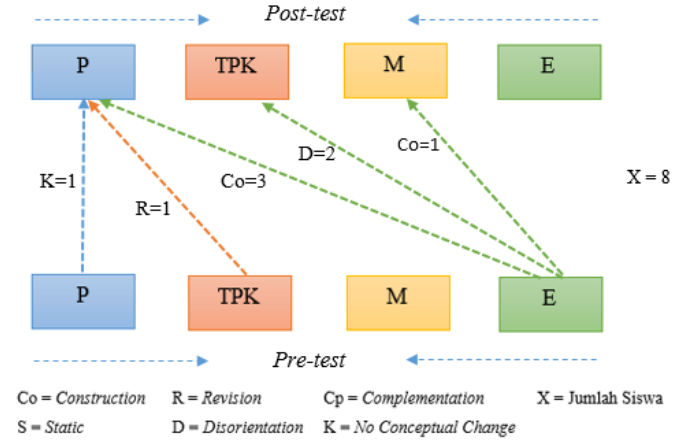

Gambar 2 Analisis Level Perubahan Konseptual Pada Indikator Definisi Momen Gaya / Torsi

Definisi momen gaya merupakan indikator dasar dalam memahami konsep dinamika rotasi. Pemahaman ini seharusnya diketahui siswa dari kegiatan-kegiatan yang sering mereka jumpai seperti membuka pintu dengan mendorong bagian pegangan di ujungnya. Namun hasil penelitian menunjukkan bahwa hanya satu siswa saja yakni siswa $C$ yang telah memahami konsep definisi momen gaya sehingga la dikategorikan dalam level perubahan konseptual no conceptual change (K). Hasil serupa juga diperoleh (Aprilianingrum dkk, 2015) yang menyatakan bahwa persentase miskonsepsi terhadap pengertian dan contohcontoh konsep momen gaya sebesar $0 \%$.

Siswa $\mathrm{G}$ mengalami level revision $(\mathrm{R})$ yakni perubahan dari tidak paham konsep menjadi paham konsep. Berdasarkan hasil obervasi, siswa $G$ menunjukkan keaktifan dalam mengajukan pertanyaan serta mengikuti proses pembelajaran dengan baik. Level complementation (Co) dialami oleh siswa $A, D, F$, dan $\mathrm{H}$ dengan perubahan dari error menjadi paham konsep. Hal tersebut terjadi karena siswa mengikuti tahap engagement dengan mengikuti diskusi konsep definisi momen gaya pada awal pembelajaran.

Pada topik mengidentifikasi penerapan momen gaya dalam kehidupan sehari-hari, level perubahan konseptual siswa seperti pada Gambar 3.

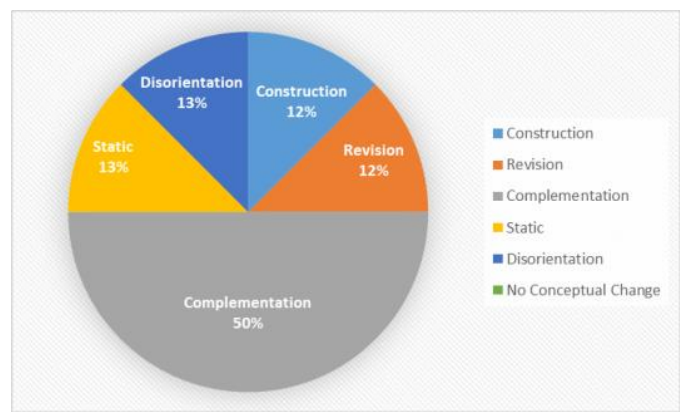

Gambar 3 Level Perubahan Konseptual Pada Topik Penerapan Momen Gaya

Analisis respon siswa indikator soal nomor 2 seperti pada Gambar 4.

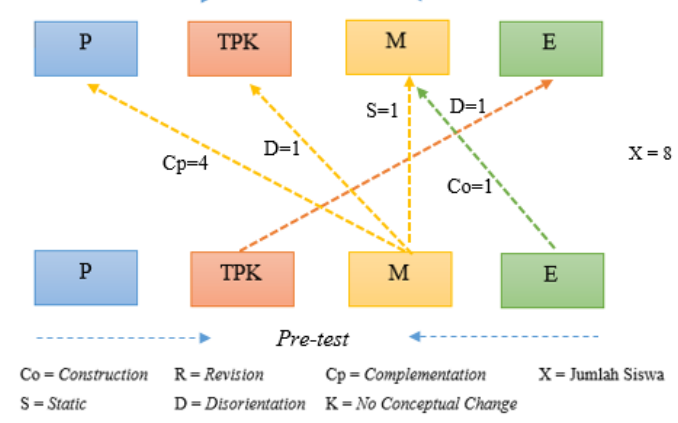

Gambar 4 Analisis Level Perubahan Konseptual Pada Indikator Penerapan Momen Gaya

Pembelajaran yang telah dilaksanakan menunjukkan adanya pemahaman siswa pada level complementation yakni siswa A, B, C, dan D. Perubahan yang dialami dari miskonsepsi menjadi paham konsep. Hal tersebut dapat terjadi karena ketika mengikuti pembelajaran tahap exploration, siswa tersebut mendemostrasikan penerapan sederhana momen gaya dan mengamati kejadiankejadian di sekitar mereka sesuai arahan guru. Kegiatan demonstrasi untuk analogi suatu konsep telah membuktikan efektivitasnya (Halim et al., 2014). Sedangkan level disorientation dialami oleh siswa $E$ dan $G$ yakni penurunan level dari tidak paham konsep menjadi error dikarenakan kurang memperhatikan demonstrasi yang dilakukan oleh teman yang lain.

Level perubaan konseptual siswa pada topik momen inersia seperti pada Gambar 5. 


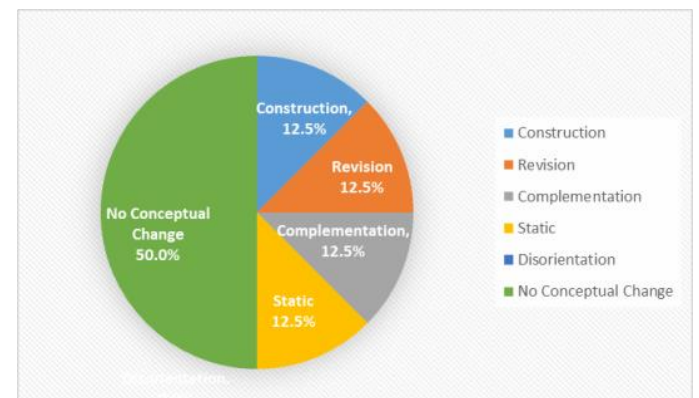

Gambar 5 Level Perubahan Konseptual Pada Topik Momen Inersia

Hasil jawaban siswa pada indikator soal nomor 3 yaitu mengidnentifikasi hal-hal yang mempengaruhi besarnya momen inersia suatu partikel massa. Perubahan kategori konsepsi siswa pada indikator ini seperti pada Gambar 6 .

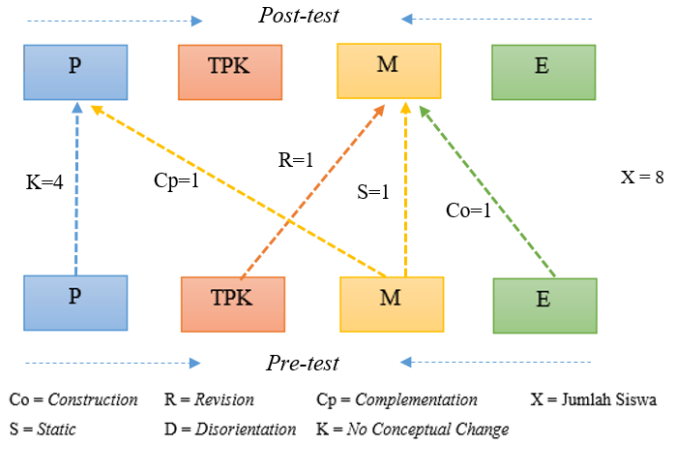

Gambar 6 Analisis Level Perubahan Konseptual Pada Indikator Faktor yang Besarnya Mempengaruhi Momen Inersia

Konsep momen inersia merupakan konsep yang masih berkesinambungan dengan momen gaya. Sehingga ketika siswa telah memahami konsep momen gaya dengan baik maka mereka dapat pula memahami konsep ini. Hasil penelitian menunjukkan bahwa siswa $\mathrm{B}, \mathrm{D}, \mathrm{E}$, dan $\mathrm{H}$ berada di level no conceptual change (K). Berdasarkan hasil observasi peneliti ketika tahap elaboration, siswa tersebut mampu menjelaskan faktor-faktor yang mempengaruhi terjadinya konsep momen inersia pada benda yang berputar dengan menghubungkan dengan konsep momen gaya. Sedangkan siswa C dan F telah memperbaiki konsep mereka setelah mengetahui penjelasan konsep dari guru.
Level perubahan konseptual siswa pada indikator soal nomor 4 yaitu mengidentifikasi besar momen gaya pada ilustrasi sebuah batang homogen seperti pada Gambar 7.

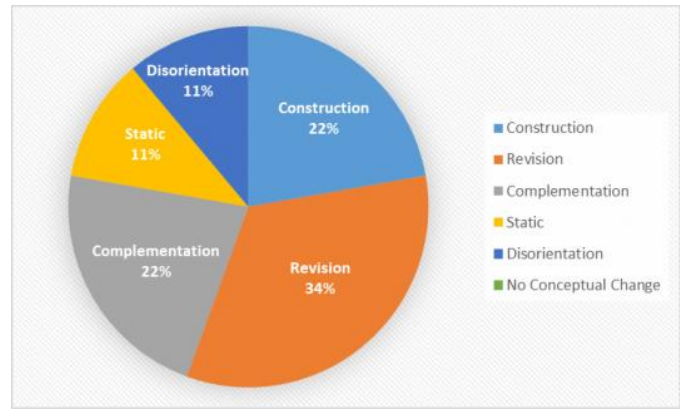

Gambar 7 Level Perubahan Konseptual Pada Topik Momen Gaya Batang Homogen

Hasil level perubahan kategori konsepsi siswa seperti pada Gambar 8.

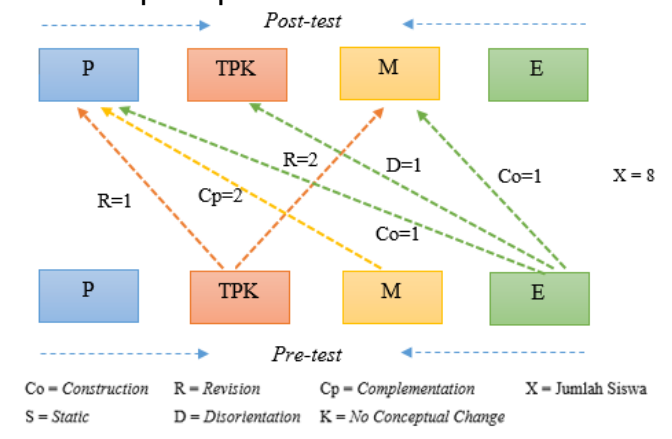

Gambar 8 Analisis Level Perubahan Konseptual Pada Topik Momen Gaya Batang Homogen

Konsep momen gaya dapat terjadi pada beberapa bentuk benda salah satunya batang homogen. Pada soal ini siswa menentukan besarnya momen gaya dengan menguraikan gaya dan mengidentifikasi letak sumbu putar. Hasil penelitian menunjukkan bahwa siswa mengalami perbaikan konsep pada level revision $(R)$ yakni siswa C, F, dan G. Ketika pembelajaran siswa tersebut berani bertanya bagaimana langkah menghitung momen gaya pada batang homogen, sehingga pada hasil post-test menunjukkan peningkatan pemahaman konsep. Akan tetapi, penelitian serupa menunjukkan bahwa siswa yang mengalami miskonsepsi pada konsep ini cukup tinggi yakni 78.3\% (Mulyastuti et al., 2016). Siswa A, B, D, dan E berada pada level complementation dan construction dimana mereka telah 
membangun pengetahuan berdasarkan penjelasan guru pada tahap explanation dan menentukan kebenaran konsep dalam menghitung besar momen gaya batang homogen pada tahap evaluation.

Level perubahan konseptual di atas menunjukkan adanya perubahan pemahaman konsep yang lebih baik yakni level construction, revision, dan complementation. Sedangkan penurunan pemahaman ke arah yang lebih buruk atau tidak ada perubahan yakni level disorientation dan static. Level disorientation dan static dialami oleh siswa pada beberapa indikator soal, namun muncul secara tidak signifikan. Sehingga, pada penelitian ini menunjukkan kecenderungan siswa berada pada level construction, revision, dan complementation. Untuk level no conceptual change tidak dapat dikategorikan sebagai perubahan konseptual karena siswa dari awal pretest hingga post-test menunjukkan pemahaman konsep yang dimiliki telah sesuai dengan konsep para ahli atau Student Knows the Term Correctly from the beginning.

Perbedaan pemahaman tiap konsep oleh siswa dipengaruhi oleh tingkat berpikirnya (Maulida, 2017). Siswa dapat menguasi semua konsep dengan baik ataupun hanya beberapa konsep tertentu. Berdasarkan analisis seluruh jawaban, siswa mengalami kecenderungan perubahan konseptual yang dialami tiap siswa seperti Gambar 9.

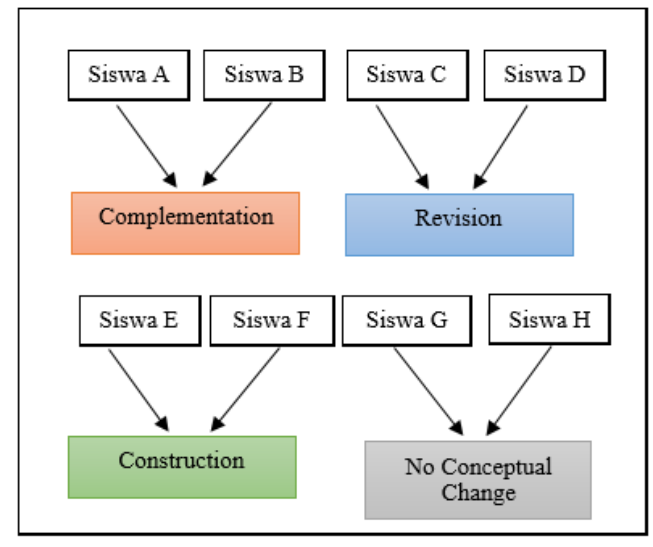

Gambar 9 Kecenderungan Level Perubahan Konseptual Siswa
Siswa A dan B pada awal pembelajaran dikategorikan miskonsepsi lalu setelah pembelajaran mereka mengalami level complementation dimana perubahan tersebut dapat terjadi dengan adanya peningkatan pemahaman yang utuh. Siswa C dan D dikategorikan dalam tidak paham konsep kemudian berada pada level revision dimana mereka memperbaiki konsep dinamika rotasi setelah pembelajaran. Siswa $E$ dan $F$ dikategorikan dalam kategori error kemudian mengalami level perubahan construction dimana mereka pada awal pembelajaran tidak tau apa-apa kemudian setelah pembelajaran mengkonstruksi pengetahuan tentang konsep. Sedangkan siswa $G$ dan $\mathrm{H}$ berada pada level no conceptual change dimana mereka tidak mengalami perubahan konseptual karena selama pembelajaran mereke cenderung aktif serta mudah dalam proses memahami konsep dinamika rotasi.

Level perubahan konseptual yang dialami oleh masing-masing siswa diharapkan menjadi tolak ukur guru untuk memberikan sebuah penanganan atau treatment yang tepat. Siswa yang mengalami level construction, sebaiknya diberikan pendampingan proses diskusi kelompok, agar setiap siswa dapat membentuk pemahaman konsep yang benar terhadap konsep yang sedang dipelajari. Guru juga dapat melaksanakan kegiatan tanya jawab suatu permasalahan untuk meningkatkan pemahaman konsep siswa dalam level complementation. Selain itu ketika siswa mengerjakan suatu evaluasi atau latihan soal, guru sebaiknya memberikan kesempatan bagi siswa untuk mandiri menemukan solusi atas permasalahan. Sehingga ketika siswa menyadari kesalahan konsep yang dimiliki maka mereka akan memperbaikinya dalam level revision. Sedangkan siswa yang telah memahami konsep dengan baik atau no conceptual change, peran guru yakni menjadi fasilitator proses pembelajaran agar siswa konsisten dalam memahami suatu konsep fisika.

Hasil perubahan konseptual yang dialami oleh siswa tentu saja karena adanya sebuah treatment yang dilaksanakan yakni model pembelajaran learning cycle 6E. Perubahan ini 
tidak hanya ditunjukkan dalam hasil nilai kognitif yang diperoleh siswa, tetapi perlu adanya pendukung hasil observasi keterlaksanaan pembelajaran. Waktu pelaksanaan observasi model pembelajaran learning cycle $6 \mathrm{E}$ yaitu selama pembelajaran berlangsung dari tahap engagement, exploration, explanation, elaboration, evaluation, dan extend. Setiap tahapan memiliki beberapa tahapan deskripsi kegiatan yang harus dilaksanaan oleh guru dan/ataupun siswa. Hasil persentase keterlaksanaan model pembelajaran learning cycle $6 \mathrm{E}$ dalam memfasilitasi perubahan konseptual seperti pada Tabel 3

Tabel 3 Persentase Keterlaksanaan Hasil

\begin{tabular}{llcc}
\multicolumn{4}{l}{ Observasi Model Pembelajaran Learning Cycle 6E } \\
\hline Sintaks & $\begin{array}{l}\text { Pertem } \\
\text { uan I }\end{array}$ & $\begin{array}{c}\text { Pertemu } \\
\text { an II }\end{array}$ & $\begin{array}{c}\% \\
\text { Keterlaks } \\
\text { anaan }\end{array}$ \\
\hline Engagement & 21 & 21 & $88 \%$ \\
\hline Exploration & 16 & 19 & $88 \%$ \\
\hline Explanation & 8 & 11 & $79 \%$ \\
\hline Elaboration & 11 & 13 & $75 \%$ \\
\hline Evaluation & 10 & 12 & $92 \%$ \\
\hline Extend & 10 & 9 & $79 \%$ \\
\hline
\end{tabular}

Berdasarkan Tabel 3 dapat diketahui bahwa rata-rata persentase keterlaksanaan pembelajaran learning cycle $6 \mathrm{E}$ yaitu $84 \%$. Sehingga keterlaksanaan pembelajaran ini dapat meningkatkan pemahaman konsep siswa sehingga terjadi perubahan konseptual ke level yang lebih baik. Perilaku siswa ketika pelaksanaan treatment model pembelajaran learning cycle $6 \mathrm{E}$ juga diamati oleh peneliti dan observer. Siswa $C$ sebagai siswa yang dikategorikan tidak paham konsep, ketika mengikuti pembelajaran memiliki keaktifan yang cukup baik. Dia mampu menjawab pertanyaan dari guru, mengerjakan tugas di kelas, dan memperhatikan penyelesaian soal yang dikerjakan oleh temannya. Begitu pula dengan siswa $\mathrm{H}$ sebagai siswa yang dikategorikan paham konsep, menunjukkan keaktifan yang tinggi. Dia berani mengerjakan soal di papan tulis dan bertanya ketika merasa bingung dengan penyampaian materi oleh guru. Sedangkan siswa E yang dikategorikan error, kurang memperhatikan penyampaian materi oleh guru dan cenderung bermain handphone sendiri. Namun ketika diberikan soal siswa $\mathrm{E}$ mampu mengerjakan dengan baik meskipun hasilnya tidak maksimal.

\section{SIMPULAN}

Analisis terhadap perubahan konseptual yang dialami oleh siswa sangat penting untuk dilaksanakan oleh pendidik. Konsepsi yang dimiliki siswa berpeluang untuk menentukan konstruksi pengetahuan yang mereka peroleh. Pelaksanaan model pembelajaran learning cycle $6 \mathrm{E}$ merupakan salah satu treatment yang dapat dipergunakan pendidik untuk meningkatkan pemahaman konsep siswa menuju level perubahan konseptual yang lebih baik. Hasil penelitian ini menunjukan perubahan level konseptual siswa mengalami meningkatan yaitu kecenderungan level perubahan siswa berada dilevel construction, complementation, dan revision.

\section{Saran}

Identifikasi konsepsi siswa sebelum mengikuti pembelajaran dan setelahnya perlu dilaksanakan oleh pendidik untuk menghindari terjadinya kesalahan pemahaman konsep atau lack of knowledge serta miskonsepsi yang dialami siswa. Perubahan pemahaman konsep dipengaruhi oleh efektivitas pelaksanaan model pembelajaran yang sesuai, dan learning cycle $6 \mathrm{E}$ dapat digunakan sebagai alternatif untuk menjadi sebuah treatment bagi siswa dalam proses perubahan konseptual kearah yang lebih baik. erdasarkan hasil penelitian ini dapat

\section{DAFTAR PUSTAKA}

Aprilianingrum, F., Jamzuri, \& Supurwoko. (2015). IDENTIFIKASI MISKONSEPSI SISWA SMA KELASXI PADA MATERI DINAMIKA ROTASI DAN KESETIMBANGAN BENDA 
TEGAR TAHUN AJARAN 2013/2014. Seminar Nasional Fisika Dan Pendidikan Fisika, 6(1), 318-323.

Arsa, P. S. (2015). Belajar dan Pembelajaran: Strategi Belajar yang Menyenangkan. Media Akademi.

Eisenkraft, A. (2003). Expanding the 5E model.

Halim, L., Yong, T. K., \& Meerah, T. S. M. (2014). Overcoming Students' Misconceptions on Forces in Equilibrium: An Action Research Study. Creative Education, 05(11), 10321042.

https://doi.org/10.4236/ce.2014.511117

Hardini, I., \& Puspitasari, D. (2015). Strategi Pembelajaran Terpadu (Teori, Konsep \& Implementasi) (Aulia (ed.)). Familia (Group Relasi Inti Media).

Hudha, M. N., Yuliati, L., \& Sutopo, S. (2016). Perubahan Konseptual Fisika Dengan Authentic Problem Melalui Integrative Learning Pada Topik Gerak Lurus Pada Sma Suryabuana Malang. Jurnal Inspirasi Pendidikan, 6(1), 733. https://doi.org/10.21067/jip.v6i1.1078

Imaniyah, I., \& Bakri, F. (2015). Pengaruh Model Pembelajaran Learning Cycle 7E Terhadap Hasil Belajar Fisika Siswa SMA. JPPPF: Jurnal Penelitian Dan Pengembangan Pendidikan Fisika p-ISSN: 2461-0933 / eISSN: 2461-1433, 1(1), 17-24. https://doi.org/doi.org/10.21009/1.01103

Kristianti, T., Widodo, A., \& Suhandono, S. (2019). The Conceptual Change Assessment BASED ON ESSAY QUESTIONS IN CASE STUDY OF DNA/RNA AND INTRON TOPICS. Jurnal Penelitian Pendidikan IPA, 4(1), 31-37.

Lappi, O. (2013). Qualitative Quantitative and Experimental Concept Possession, Criteria for Identifying Conceptual Change in Science Education. Science and Education, 22(6), 1347-1359. https://doi.org/10.1007/s11191012-9459-3

Lisma, Kurniawan, Y., \& Sulastri, E. (2017). PENERAPAN MODEL LEARNING CYCLE (LC) 7E SEBAGAI UPAYA PENINGKATAN PEMAHAMAN KONSEP ASPEK
MENAFSIRKAN DAN MENYIMPULKAN PADA MATERI KALOR KELAS $X$ SMA. Jurnal IImu Pendidikan Fisika, 2(2), 35-37.

Maulida, A. (2017). Penerapan Instrumen ThreeTier Test untuk Mengidentifikasi Miskonsepsi Siswa SMA pada Materi Keseimbangan Benda Tegar. JURNAL PHENOMENON, 07(2), 88-98.

Mulyastuti, H., Setyarsih, W., \& J, M. N. R. (2016). Profil Reduksi Miskonsepsi Siswa Materi Dinamika Rotasi Sebagai Pengaruh Penerapan Model Pembelajaran ECIRR Berbantuan Media Audiovisual. Jurnal Inovasi Pendidikan Fisika (JIPF), 05(02), 8284.

Ozge, H. A. (2014). THE EFFECT OF 5E LEARNING CYCLE INSTRUCTION ON 10TH GRADE STUDENTS' UNDERSTANDING OF CELL DIVISION AND REPRODUCTION CONCEPTS (IsSUE June). MIDDLE EAST TECHNICAL UNIVERSITY.

Partini, Budijanto, \& Bachri, S. (2017). PENERAPAN MODEL PEMBELAJARAN LEARNING CYCLE 7E UNTUK MENINGKATKAN KEMAMPUAN. Journal Pendidikan: Teori, Penelitian, Dan Pengembangan EISSN: 2502-471X Bulan Februari Tahun 2017, 2(2), 268-272.

Sadia, I. W. (2014). Model-model Pembelajaran Sains Konstruktivistik. Graha IImu.

Sari, R. P., \& Rahmatan, H. (2017). PENERAPAN MODEL PEMBELAJARAN LEARNING CYCLE 7E UNTUK MENINGKATKAN MOTIVASI DAN HASIL BELAJAR PESERTA DIDIK DI SMP. Jurnal Pendidikan Sains Indonesia, 05(02), 68-74.

Sulastri, E., \& Hikmawati. (2018). PENGARUH MODEL LEARNING CYCLE 7E TERHADAP HASIL BELAJAR FISIKA SISWA KELAS XI SMAN 8 MATARAM. Jurnal Pendidikan Fisika Dan Teknologi, 4(1), 56-65.

Suratno, T. (2008). Konstruktivisme, Konsepsi Alternatif dan Perubahan Konseptual dalam Pendidikan IPA. 1985-1987.

Sutirman. (2013). Media dan Model-Model Pembelajaran Inovatif. Graha IImu. 
Syahrul, D. A., \& Setyarsih, W. (2015). Identifikasi Miskonsepsi dan Penyebab Miskonsepsi Siswa dengan Three-tier Diagnostic Test Pada Materi Dinamika Rotasi. Jurnal Inovasi Pendidikan Fisika (JIPF), 04(03), 67-70.

Veronika, T. (2017). Pengaruh Model Pembelajaran Learning Cycle 5E Terhadap Penguasaan Konsep Sistem Peredaran Darah Manusia Siswa Kelas VIII SMP Negeri 19 Palembang.

Zubaidah, S., \& Lestari, U. (2016). PENERAPAN
MODEL PEMBELAJARAN LEARNING CYCLE 5E BERBANTUAN PETA KONSEP UNTUK MENINGKATKAN PEMAHAMAN KONSEP DAN HASIL BELAJAR SISWA KELAS XI SMA LABORATORIUM UM. January 2018.

Zuhra, F., Hasan, M., \& Safitri, R. (2017). MODEL PEMBELAJARAN LEARNING CYCLE7E BERBANTUAN BUKU SAKU TERHADAP HASIL BELAJAR SISWA SMA. Jurnal Pendidikan Sains Indonesia, 05(01), 134139. 